\title{
Upaya Meningkatkan Kemampuan Pemahaman Konsep dan Percaya Diri Siswa Melalui Model Guided Discovery Learning
}

\author{
Tyas Ayun Endramawati
}

\author{
SMA Negeri 8 Yogyakarta, Indonesia \\ Tyasayune75@gmail.com
}

\begin{abstract}
Abstrak
Penelitian ini bertujuan untuk meningkatkan kemampuan pemahaman konsep dan percaya diri siswa melalui penerapan model guided discovery learning. Penelitian ini termasuk jenis penelitian tindakan kelas, yang terdiri atas tiga siklus dimana tiap siklus satu kali pertemuan yang melalui tahap perencanaan, pelaksanaan, pengamatan dan refleksi. Subjek dari penelitian ini adalah 36 siswa kelas XI MIPA 1 SMA Negeri 8 Yogyakarta. Materi yang digunakan adalah transformasi geometri. Instrumen pengambilan data yang digunakan meliputi tes tertulis pemahaman konsep, lembar angket sikap percaya diri dan dokumentasi. Teknik pengumpulan data yang digunakan adalah tes, angket dan dokumentasi. Teknik analisis data yang digunakan adalah data hasil tes dan data hasil angket. Hasil penelitian menunjukan adanya peningkatan kemampuan pemahaman konsep siswa. Hal ini terlihat pada siklus 1 diperoleh siswa yang termasuk kategori tinggi sebesar $33 \%$, pada siklus 2 diperoleh siswa yang termasuk kategori tinggi sebesar $47 \%$ dan pada siklus 3 diperoleh siswa yang termasuk kategori tinggi sebesar $72 \%$. Sedangkan pada sikap percaya diri siswa juga terdapat peningkatan. Hal ini terlihat pada siklus 1 diperoleh siswa yang termasuk kategori tinggi sebesar 33\%, pada siklus 2 diperoleh siswa yang termasuk kategori tinggi sebesar $47 \%$ dan pada siklus 3 diperoleh siswa yang termasuk kategori tinggi sebesar $75 \%$. Dari hasil yang diperoleh, dapat diambil simpulan bahwa penerapan model Guided Discovery Learning dapat meningkatkan kemampuan pemahaman konsep dan sikap percaya diri siswa pada pembelajaran matematika. Berdasarkan hasil penelitian, maka guru disarankan untuk menerapkan model Guided Discovery Learning.

Katakunci: Guided Discovery Learning, Kemampuan Pemahaman Konsep, Percaya Diri
\end{abstract}

Abstrack

This study aims to improve students' conceptual understanding and confidence through the application of the guided discovery learning model. This research is a classroom action research, which consists of three cycles in which each cycle has one meeting which goes through the stages of planning, implementing, observing and reflecting. The subjects of this study were 36 students of class XI MIPA 1 SMA Negeri 8 Yogyakarta. The material used is a geometric transformation. The data collection instruments used included a written test of concept understanding, a self-confidence questionnaire sheet and documentation. The data collection techniques used were tests, questionnaires and documentation. The data analysis technique used was test result data and questionnaire result data. The results showed an increase in students' conceptual understanding skills. This can be seen in cycle 1 obtained students who are in the high category by 33\%, in cycle 2 obtained students who are in the high category by $47 \%$ and in cycle 3 obtained students who are in the high category by $72 \%$. Meanwhile, students' self-confidence also increased. This can be seen in cycle 1 obtained by students who are in the high category by 33\%, in cycle 2 it is obtained students who are in the high category by $47 \%$ and in cycle 3 obtained students who are in the high category by 75\%. From the results obtained, it can be concluded that the application of the Guided Discovery 
Learning model can improve the conceptual understanding and confidence of students in learning mathematics. Based on the research results, it is recommended that teachers apply the Guided Discovery Learning model. Keywords: Guided Discovery Learning, Concept Understanding Ability, Self Confidence

\section{PENDAHULUAN}

Matematika memiliki peranan penting dalam kehidupan sehari-hari (Nuraeni dan Luritawaty, 2017: 442). Matematika juga merupakan salah satu bagian penting dalam upaya menguasai dan menciptakan teknologi di masa depan (Depdiknas: 2006). Oleh karena itu matematika menjadi salah satu mata pelajaran yang diajarkan pada setiap jenjang pendidikan di Indonesia mulai dari jenjang pendidikan dasar, pendidikan menengah hingga ke perguruan tinggi. Wardhani (2008) mengatakan bahwa tujuan pembelajaran matematika yaitu agar siswa mampu 1) Memahami konsep matematika, menjelaskan keterkaitan antar konsep dan mengaplikasikan konsep atau algoritma secara luwes, akurat, efisien, dan tepat dalam pemecahan masalah, 2) Menggunakan penalaran pada pola dan sifat, melakukan manipulasi matematika dalam membuat generalisasi, menyusun bukti, atau menjelaskan gagasan dan pernyataan matematika, 3) Memecahkan masalah yang meliputi kemampuan memahami masalah, merancang model matematika, menyelesaikan model, dan menafsirkan solusi yang diperoleh, 4) Mengkomunikasikan gagasan dengan simbol, tabel, diagram atau media lain untuk memperjelas keadaan atau masalah, dan 5) Memiliki sikap menghargai kegunaan matematika dalam kehidupan, yaitu memiliki rasa ingin tahu, perhatian, dan minat dalam mempelajari matematika serta sikap ulet dan percaya diri dalam pemecahan masalah. Berdasarkan tujuan pembelajaran tersebut, salah satu tujuan utama pembelajaran matematika adalah memahami konsep matematika.

Adapun indikator pemahaman konsep menurut Peraturan Dirjen Dikdamen Nomor 506/C/Kep/PP/2004 tanggal 11 November 2001 adalah 1) Menyatakan ulang sebuah konsep, 2) Mengklasififikasi objek menurut tertentu sesuai dengan konsepnya, 3) Memberikan contoh dan bukan contoh dari suatu konsep, 4) Menyajikan konsep dalam berbagai bentuk representasi matematis,

Mengembangkan syarat perlu atau syarat cuku dari suatu konsep, 6) Menggunakan dan memanfaatkan serta memilih prosedur atau operasi tertentu, dan 7) Mengaplikasikan konsep atau algoritma dalam pemecahan masalah.

Saat ini Pemerintah sedang menggalakan pendidikan karakter pada semua jenjang pendidikan. Berdasarkan 
hasil studi TIMSS (Ambarwati, 2015) diperoleh bahwa tingkat percaya diri pada "skala internasional" hanya terdapat $14 \%$ siswa yang memiliki percaya diri (self-confidence) tinggi terkait kemampuan matematikanya. Sedangkan 5\% siswa termasuk dalam kategori sedang, dan $41 \%$ sisanya dalam kategori rendah. Hal ini juga terjadi pada siswa di Indonesia. Terdapat $3 \%$ siswa yang memiliki percaya diri tinggi dalam matematika, sedangkan $52 \%$ termasuk dalam kategori sedang dan 45\% termasuk dalam kategori rendah". Sehingga untuk meningkatkan rasa percaya diri siswa perlu dilatih sejak dini.

Sebagian besar siswa Indonesia masih merasakan kesusahan dalam belajar matematika khususnya pada materi transformasi geometri. Padahal soal yang diberikan guru merupakan soal rutin yang menuntut kemampuan pemahaman konsep siswa. Siswa tidak mampu mengemukakan alasan-alasan dari suatu konsep tertentu. Siswa juga tidak mampu menghubungkan benda nyata, gambar maupun soal-soal cerita ke dalam ide matematika. Hal ini terjadi karena rendahnya kemampuan pemahaman konsep yang dimiliki siswa. Agar kemampuan pemahaman konsep matematis siswa berkembang secara optimal, siswa harus mampu mengkonstruksi pengetahuannya sendiri dengan cara mengaitkan pengetahuan yang dipelajari dengan dunia nyata. Salah satu upaya yang dapat dilakukan guru dengan cara merancang pembelajaran yang lebih berpusat pada siswa, sehingga siswa sendiri yang terlibat aktif dalam membangun pengetahuannya agar tercipta pembelajaran yang bermakna (Suryanti, Khikmiyah, Zawawi, \& Fauziyah, 2014). Siswa juga merasa kurang percaya diri dalam mengerjakan soal yang diberikan guru, mereka merasa ragu jawaban yang mereka kerjakan benar atau tidak. Hal ini menyebabkan rendahnya hasil belajar siswa. sehingga dapat ditarik sebuah makna bahwa siswa memiliki kemampuan pemahaman konsep dan sikap percaya diri masih rendah. Padahal, pembelajaran matematika yang diberikan di sekolah mengharapkan adanya penguasaan kemampuan pemahaman konsep dan mengembangkan sikap percaya diri. Oleh karena itu, diperlukan suatu model pembelajaran yang dapat mengakomodasi kedua hal tersebut.

Salah satu model pembelajaran yang sesuai untuk meningkatkan pemahaman konsep matematik dan sikap percaya diri adalah model Guided Discovery Learning. Menurut Kemdikbud (2013), Guided Discovery Learning adalah proses pembelajaran yang terjadi bila pelajar tidak disajikan dengan pelajaran dalam bentuk finalnya. Model Guided Discovery 
Learning memiliki kelebihan antara lain:

(1) Strategi penemuan membangkitkan gairah pada siswa karena menyebabkan siswa mengarahkan sendiri cara belajarnya; (2) Model ini memberi kesempatan kepada siswa untuk bergerak maju sesuai dengan kemampuannya sendiri. (3) Siswa akan mengerti konsep dasar dan ide-ide lebih baik; dan (4) Mendorong siswa berpikir dan bekerja atas inisiatif sendiri. Adapun langkah-langkah model Guided Discovery Learning yang dipakai dalam penelitian ini meliputi:

Stimulation (stimulasi/pemberian rangsangan),

Problem statement (identifikasi masalah),

(3) Data collection (pengumpulan data). (4)

Data processing (pengolahan data), (5)

Verification (pembuktian) dan (6)

Generalization (menarik kesimpulan).

Latar belakang ini kemudian melandasi peneliti untuk membuat bahan ajar berupa Lembar Kerja Siswa (LKPD) dengan metode guided discovery learning agar dapat mengembangkan kemampuan pemahaman konsep materi transformasi geometri.

\section{METODE}

Penelitian ini merupakan Penelitian Tindakan Kelas (PTK) yang dilakukan di kelas XI MIPA 1 SMA Negeri 8 Yogyakarta dengan jumlah siswa sebanyak 36 orang. Subjek pelaku tindakan adalah peneliti sendiri selaku guru mata pelajaran matematika dan subjek pembantu adalah teman sejawat. Sedangkan objek dari penelitian ini adalah kemampuan pemahaman konsep dan sikap percaya diri siswa. Tujuan dari penelitian ini antara lain (1) untuk meningkatkan kemampuan pemahaman konsep siswa pada materi transformasi geometri di kelas XI MIPA 1 SMA Negeri 8 Yogyakarta melalui penerapan model Guided Discovery Learning. (2) untuk meningkatkan sikap percaya diri siswa pada materi transformasi geometri XI MIPA 1 SMA Negeri 8 Yogyakarta melalui penerapan model Guided Discovery Learning.

Penelitian ini berlangsung selama 3 kali pertemuan yang terbagi menjadi tiga siklus. Siklus pertama dilaksanakan selama 1 kali pertemuan (2 jam pelajaran), siklus kedua dilaksanakan selama 1 kali pertemuan (2 jam pelajaran) dan siklus ketiga juga kedua dilaksanakan selama 1 kali pertemuan (2 jam pelajaran). Setiap siklus terdiri atas tahap perencanaan tindakan, pelaksanaan tindakan, observasi, refleksi dan evaluasi. Kegiatan penelitian dalam setiap siklus dimulai dengan merencanakan kegiatan yang akan diimplementasikan dalam tahap pelaksanaan tindakan. Selama pelaksanaan tindakan, peneliti melaksanakan observasi untuk 
mendapatkan data dan informasi. Data dan informasi yang terkumpul pada tahap ini akan dianalisis sebagai bahan refleksi. Rekfleksi pada dasarya dilakukan selama penelitian berlangsung. Refleksi pada setiap akhir pertemuan dilakukan untuk memberikan umpan balik dalam perbaikan pelaksanaan pembelajaran berikutnya. Sedangkan refleksi pada setiap akhir siklus dilakukan untuk memberikan gambaran perubahan dan perbaikan pelaksanaan tindakan pada siklus berikutnya. Instrumen yang digunakan dalam penelitian ini antara lain (1) tes tertulis guna mengetahui kemampuan penalaran matematik siswa, (2) lembar angket digunakan untuk mengetahui respon percaya diri siswa, dan (3) dokumentasi berupa foto yang digunakan untuk membantu menggambarkan apa yang terjadi di kelas pada waktu pembelajaran berlangsung. Ketiga data tersebut diperoleh dengan memberikan tes kepada siswa pada akhir siklus I, siklus II dan siklus III.

Metode pengumpulan data yang digunakan adalah metode tes dan metode angket. Sedangkan teknik analisis data yang digunakan adalah data hasil tes tertulis dan data hasil angket percaya diri siswa. Jenis data yang akan diperoleh adalah data kuantitatif dan data kualitatif. Data yang diperoleh melalui tes belajar dianalisis secara kuantitatif dengan pengujian statistika deskriptif. Analisis data kuantitatif menggunakan statistika dekriptif bertujuan untuk menggambarkan karakteristik distributif responden untuk masingmasing perlakuan. Adapun kriteria yang digunakan untuk menentukan kategori skor kemampuan pemahaman konsep matematika siswa (Arikunto, 2006:1819) tersaji pada Tabel 1 berikut.

Tabel 1. Kualifikasi Pemahaman Konsep

\begin{tabular}{cc}
\hline Persentase & Kriteria \\
\hline $80 \%<\bar{x} \leq 100 \%$ & Sangat Tinggi \\
\hline $60 \%<\bar{x} \leq 80 \%$ & Tinggi \\
\hline $40 \%<\bar{x} \leq 60 \%$ & Sedang \\
\hline $20 \%<\bar{x} \leq 40 \%$ & Kurang \\
\hline $0 \%<\bar{x} \leq 20 \%$ & Rendah \\
\hline
\end{tabular}

Sedangkan kriteria yang digunakan untuk menentukan kategori karakter percaya diri siswa (Arikunto, 2008) tersaji pada Tabel 2 berikut.

Tabel 2. Kategorisasi Tingkat Percaya Diri

\begin{tabular}{lcc}
\hline \multicolumn{1}{c}{ Kriteria Skor } & Kriteria Penilaian & Kategori \\
\hline Lebih dari $(\mathrm{M}+(1,5$ dari $\mathrm{SD}))$ & $>65$ & Sangat tinggi \\
\hline $\mathrm{M}$ sampai dengan $(\mathrm{M}+(1,5$ dari SD) $)$ & $50-64$ & Tinggi \\
\hline$(\mathrm{M}-(1,5$ dari SD) $)$ sampai dengan $\mathrm{M}$ & $35-49$ & Rendah \\
\hline
\end{tabular}


Kurang dari $(\mathrm{M}-(1,5$ dari SD))

HASIL DAN PEMBAHASAN

Berdasarkan hasil penelitian menggunakan model Guided Discovery Learning diperoleh gambaran tentang
$<35$

Sangat rendah

peningkatan kemampuan pemahaman konsep siswa kelas XI MIPA 1 ditunjukkan pada Tabel 3.

Tabel 3. Persentase Skor Kemampuan Pemahaman Konsep Siswa

\begin{tabular}{ccccccc}
\hline No & $\begin{array}{c}\text { Jenis } \\
\text { Siklus }\end{array}$ & $\begin{array}{c}\text { Kategori } \\
\text { Sangat Tinggi }\end{array}$ & $\begin{array}{c}\text { Kategori } \\
\text { Tinggi }\end{array}$ & $\begin{array}{c}\text { Kategori } \\
\text { Sedang }\end{array}$ & $\begin{array}{c}\text { Kategori } \\
\text { Kurang }\end{array}$ & $\begin{array}{c}\text { Kategori } \\
\text { Rendah }\end{array}$ \\
\hline 1 & Siklus I & $0 \%$ & $33 \%$ & $67 \%$ & $0 \%$ & $0 \%$ \\
\hline 2 & Siklus II & $0 \%$ & $47 \%$ & $53 \%$ & $0 \%$ & $0 \%$ \\
\hline 3 & Siklus III & $0 \%$ & $72 \%$ & $28 \%$ & $0 \%$ & $0 \%$
\end{tabular}

Berdasarkan Tabel 3 pada akhir siklus I dari 36 siswa XI MIPA 1 yang mengikuti tes evaluasi, diperoleh persentase siswa yang termasuk kategori sangat tinggi sebesar $0 \%$, yang termasuk kategori tinggi sebesar 33\%, yang termasuk kategori sedang sebesar $67 \%$, yang termasuk kategori sebesar $0 \%$, dan yang termasuk kategori rendah sebesar $0 \%$. Hasil yang diperoleh pada siklus I belum memenuhi indikator keberhasilan penelitian dikarenakan hasil dari tes evaluasi kemampuan pemahaman konsep siswa belum mencapai mencapai ketuntasan 70\% dengan kategori tinggi.

Pada akhir siklus II dari 36 siswa XI MIPA 1 yang mengikuti tes evaluasi, diperoleh persentase siswa yang termasuk kategori sangat tinggi sebesar $0 \%$, yang termasuk kategori tinggi sebesar 47\%, yang termasuk kategori sedang sebesar 53\%, yang termasuk kategori sebesar 0\%, dan yang termasuk kategori rendah sebesar $0 \%$. Ini menunjukkan bahwa ada peningkatan siswa yang memiliki kemampuan pemahaman konsep, walaupun hanya mengalami sedikit perubahan. Hal ini mungkin disebabkan materi yang diberikan pada siklus II cenderung lebih sukar dibandingkan dengan materi yang diberikan pada siklus I. Hasil yang diperoleh pada siklus II belum memenuhi indikator keberhasilan penelitian dikarenakan hasil dari tes evaluasi kemampuan pemahaman konsep siswa belum mencapai mencapai ketuntasan $70 \%$ dengan kategori tinggi.

Pada akhir siklus III dari 36 siswa XI MIPA 1 yang mengikuti tes evaluasi, diperoleh diperoleh persentase siswa yang termasuk kategori sangat tinggi 
sebesar $0 \%$, yang termasuk kategori tinggi sebesar $72 \%$, yang termasuk kategori sedang sebesar 28\%, yang termasuk kategori sebesar $0 \%$, dan yang termasuk kategori rendah sebesar $0 \%$. Hasil yang diperoleh pada siklus III sudah memenuhi indikator keberhasilan penelitian dikarenakan hasil dari tes evaluasi kemampuan pemahaman konsep siswa sudah mencapai mencapai ketuntasan $70 \%$ dengan kategori tinggi.

Berdasarkan hasil angket siswa saat pembelajaran menggunakan model Guided Discovery Learning diperoleh gambaran persentase skor percaya diri siswa kelas XI MIPA 1 yaang tersaji pada Tabel 4 berikut.

Tabel 4. Persentase Skor Percaya Diri

\begin{tabular}{clcccc}
\hline No & Jenis Siklus & $\begin{array}{c}\text { Kategori Sangat } \\
\text { Tinggi }\end{array}$ & $\begin{array}{c}\text { Kategori } \\
\text { Tinggi }\end{array}$ & $\begin{array}{c}\text { Kategori } \\
\text { Rendah }\end{array}$ & $\begin{array}{c}\text { Kategori Sangat } \\
\text { Rendah }\end{array}$ \\
\hline 1 & Siklus I & $0 \%$ & $33 \%$ & $64 \%$ & $3 \%$ \\
\hline 2 & Siklus II & $0 \%$ & $47 \%$ & $53 \%$ & $0 \%$ \\
\hline 3 & Siklus III & $0 \%$ & $75 \%$ & $25 \%$ & $0 \%$ \\
\hline
\end{tabular}

Dari Tabel 4 diketahui bahwa untuk persentase percaya diri siswa kelas XI MIPA 1 sebesar 33\% pada kategori tinggi. Pada pembelajaran pada siklus I, siswa masih banyak yang masih mengalami keraguan dalam menyampaikan pendapat, takut mengajukan pertanyaan dan sulit menjawab pertanyaan dari guru dalam mengikuti pembelajaran matematika.

Pada akhir siklus 2 persentase percaya diri siswa kelas XI MIPA 1 naik menjadi $47 \%$ pada kategori tinggi. Hal ini disebabkan oleh pelaksanaan pembelajaran pada siklus II terjadi interaksi guru dan siswa yang lebih baik. Pada siklus ini, siswa lebih tertib dalam proses pembelajaran matematika dan siswa lebih menunjukan eksistensi dirinya melalui aktif mengajukan ide, gagasan dan pertanyaan.
Pada akhir siklus 3 persentase percaya diri siswa kelas XI MIPA 1 naik menjadi $75 \%$ pada kategori tinggi. Hal ini disebabkan oleh pelaksanaan pembelajaran pada siklus III terjadi interaksi guru dan siswa yang lebih baik. Pada siklus ini, siswa mempunyai inisiatif untuk mengerjakan soal yang diberikan oleh guru tanpa ditunjuk oleh guru sebelumnya. Siswa mengerjakan semua kegiatan pada LKPD melalui kegiatan diskusi kelompok. Hal tersebut terlihat dari partisipasi siswa dalam kegiatan kelompok lebih terlihat dan antusias siswa untuk mempresentasikan hasil diskusinya.

Hasil terkait angket siswa tentang sikap percaya diri pada siklus III di atas membuktikan bahwa penerapan model guided discovery learning dapat 
meningkatkan sikap percaya diri siswa kelas XI MIPA 1 SMA Negeri 8 Yogyakarta. Dengan demikian tujuan penelitian dan indikator keberhasilan telah tercapai, rumusan masalah telah terpecahkan, dan hipotesis penelitian telah terbukti.

Berdasarkan analisis data dan pembahasan yang telah dilakukan, maka dapat disimpulkan bahwa penerapan model guided discovery learning dapat meningkatkan kemampuan pemahaman konsep dan sikap percaya diri siswa kelas X MIPA 1 SMA Negeri 8 Yogyakarta, sebagaimana hasil penelitian yang serupa bahwa penerapan pembelajaran discovery learning dapat meningkatkan kemampuan pemahaman konsep (Suryanti, 2015).

\section{Ucapan Terima Kasih}

Peneliti mengucapkan terimakasih kepada civitas akademika SMA Negeri 8 Yogyakarta, Ibu Sri Suryanti, M.Si dan Ibu Dra. Masfufah yang telah berkonstribusi dalam penelitian ini.

\section{Daftar Pustaka}

Ambarwati, R. 2015. Keefektifan Model Project Based Learning Berbasis GQM Terhadap Kemampuan Komunikasi Matematis Dan Percaya Diri Peserta didik Kelas VII. Unnes Journal of Mathematics Education. 4(1). (Online). (http://journal.unnes.ac.id/sju/in dex.php/ujme/article/view/7601/ $\underline{5263}$ diunduh tanggal 17 November 2020).

Arikunto, S. 2006. Prosedur Penelitian Suatu Pendekatan Praktik. Jakarta: PT Asdi Mahasatya.

Arikunto, S. 2008. Dasar-Dasar Evaluasi Pendidikan. Jakarta: PT.Bumi Aksara.

Afrilianto, M. (2012). Pembelajaran Matematika dengan Pendekatan Metaphorical Thinking untuk Meningkatkan Pemahaman Konsep dan Kompetensi Strategis Matematis Siswa. Tesis Pendidikan Matematika Universitas Pendidikan Indonesia. Bandung: Tidak ditebitkan.

Depdiknas. (2006). Kurikulum 2006: Standar Isi Mata Pelajaran Matematika untuk SMP/MTs. Jakarta: Ditjen Kurniawan,R. (2009). Kemampuan Pemahaman dan Pemecahan Masalah Matematik Serta Pembelajaran Kontekstual. Skripsi pada Jurusan Pendidikan Matematika STKIP Yasika Majalengka (online). Tersedia: http://rudyks3majalengka.blogspot.in/2009/01/kema mpuan-pemahaman-danpemecahan.html [17 November 2020]

Fitriyani, I., \& Zaenuri. 2017. Unnes Journal of Mathematics Education Research Kemampuan Literasi Matematika Siswa Ditinjau dari Kecerdasan Emosional Pada Pembelajaran Cps Berbantuan Hands On Activity. Unnes Journal of Mathematics Education Research, 6(2), 139-147. 
Kemdikbud. 2013. Model Pembelajaran Berbasis Penemuan (Discovery Learning) Di Sekolah Dasar. Jakarta: Direktorat Pembinaan SdDitjen Dikdas.

Maretasani, L. D., \& Dwijanto. 2016. Kemampuan Pemecahan Masalah dan Metakognisi Berdasarkan Orientasi Tujuan pada Pembelajaran Berbasis Masalah. Unnes Journal of Mathematics Education Research, 5(2).

Nuraeni, R., \& Luritawaty, I. P. (2017). Perbandingan Kemampuan

Pemahaman Matematis Siswa Antara Yang Menggunakan Pembelajaran Inside-Outside-Circle Dengan Konvensional. Mosharafa: Jurnal Pendidikan Matematika. 6(3):442.

Purwanto, N. 1995. Psikologi Pendidikan. Bandung: Remaja Rosdakarya.

Sanjaya, W. 2011. Strategi Pembelajaran Berorientasi Standar Proses Pendidikan. Jakarta: Kencana Prenada Media.
Suryanti, S. (2015). Peningkatan kepercayaan diri dan kemampuan pemecahan masalah mahasiswa pada mata kuliah matematika diskrit melalui discovery learning. DIDAKTIKA: Jurnal Pemikiran Pendidikan, 22(1), 64-73. https://doi.org/doi:10.1234/didakti ka.v22i1.148

Suryanti, S., Khikmiyah, F., Zawawi, I., \& Fauziyah, S. (2014). Peningkatan Penguasaan Konsep Matriks Melalui Model Pembelajaran Kooperatif Tipe Two Stay Two Stray (Tsts). DIDAKTIKA: Jurnal Pemikiran Pendidikan, 21(1), 14-27.

Wardhani, S. (2008). Analisis SI dan SKL Mata Pelajaran Matematika SMP/MTs untuk Optimalisasi Tujuan Mata Pelajaran Matematika.Yogyakarta: PPPPTK.

Winataputra, U. S. (2007). Teori belajar dan pembelajaran. Jakarta:

Universitas Terbuka. 
